\title{
無線 LAN 対応繊維強化セメント板 3 層型電波吸収体に関する検討 A STUDY ON THE THREE LAYERS TYPE EM WAVE ABSORBER BY USING FIBER REINFORCEMENT CEMENT BOARD FOR WIRELESS LAN
}

\author{
木 村 健 一*，橋 本 修** \\ Ken-ichi KIMURA and Osamu HASHIMOTO
}

\begin{abstract}
Recently, wireless LAN is widely used around/inside building, and some problems have been appeared, such as multi path fading or security. Some EM-wave absorbers are proposed to solve above problems. In this situation, three layer type absorber by using common building materials is presented. In this paper, first three steps of design procedure are introduced. Secondary, the frequency of the temperature and relative humidity for the experimental room are investigated in order to estimate the condition of setting environment, and the variation of the water contents for the fiber reinforced cement boards are estimated. Lastly, comparison of measured absorption and calculated one for experimental absorber to confirm the validity of the design procedure and effectiveness of the absorber.
\end{abstract}

Keywords: EM-wave Absorber, Wireless LAN, Fiber Reinforced Cement Board, Complex permittivity, Water Content 電波吸収体, 無線 LAN, 緎維強化セメント板, 複素比誘電率, 含水率

1.はじめに

ユビキタス社会の到来が論じられる中, その情報インフラの一つ として無線 LAN が急速に普及してきている。これは, 2000 年の IEEE802.11b の規格統一による価格の低下と，その後の IEEE802.11 各タスクグループの更なる規格統一 1)の動きに呼応し た様々な製品の開発実用化に起因している。

それに伴って, 無線 LAN の使用に関しての問題点ーマルチパスフ エージングなどによる通信品質の劣化やセキュリティ問題などーも 顥在化してきている。これに対して，機器側の対策としては, OFDM などの新たな変調方式の採用・誤り訂正の新しいアルゴリズムの開 発やアンテナなどの改善によってマルチパス環境への対応を改善し たり, 802.11x などによる新規格の提案によるセキュリティ問題への 対応をおこなったりしている。一方，設置環境側の対策としては， 電波吸収体の設置によるマルチパスへの対応や電磁シールド材によ る漏洩電波の低減などの対策が提案・実証されている。

無線 LAN の使用周波数帯域 $(2.4 \mathrm{GHz} \sim 2.5 \mathrm{GHz}$ 及び $5.15 \mathrm{GHz}$ $\sim 5.25 \mathrm{GHz}$ ）を含む $1 \mathrm{GHz} \sim 10 \mathrm{GHz}$ の周波数に対応した電波吸収体 は，既にいくつかのものが提案されている。しかしそれらは一般の 建築材料と比較して高価で, 加工性や取り扱いに問題があるなど, 実 際の施工を考慮した場合には，いくつかの制約があるのが現状であ る。無線 LAN 用の吸収体に要求される項目 2) としては, 対応周波数
帯域 ( 2 つ無線 LAN 使用周波数帯域幅各 $100 \mathrm{MHz}$ に斜入射も含 めて対忘したものであること), 対人調和性（形状や構成要素に安全 性や環境適応規淮が要求させるほか, 景観やレイアウトとの調和も 必要), 低コスト (無線 LAN 機器の低コスト化に対応したものであ ることが必要）等が考えられる。これに対して，既に提案されてい る無線 LAN 用の吸収体は，抵抗皮膜などの導電性材料を使った $\lambda / 4$ 型，磁性材料を使った磁性材料型，建材を主とした建材型の（混合 型を含めて）3つに大別できる。このうち建材型吸収体としては, 般の建築材料をべースに誘電体や磁性体を混入したもの ${ }^{3}$, 抵抗皮膜 を塗布したりするもの4)などが報告されている。しかし、これらは無 線 LAN 用の吸収体としての先の 3 つの要求項目から考えるといく つかの点で十分とはいえない状況である。

このような背景の下で，筆者らは無線通信を快適に行うための電 磁環境の構築を目指して研究開発を行ってきており，既に一般建材を 対象として, 複素比誘電率の評価手法 5)や材料のばらつきの評価 6)を 行っている。そして, 建材型吸収体として一般建材のみを用いた 3 層 型電波吸収体 (建材 2 層の間に空気層を挟み込むことによって周波数 帯域幅を広げ，斜入射に対しても有効なように工夫を行ったもの)を 提案 》した。建材型吸収体は，用いる材料が窯業系であるため，含水 率の変動や, 材料のばらつきによって, 吸収性能に大きな変動が予想 される。そこで本検討では, 吸収体の設計法を説明した上で, 内装用
**侏フジタ技術センター 主任研究員・工博

** 青山学院大学理工学部 教授·工博
Researcher, Technology Development Division, Fujita Corporation, Dr. Eng. Prof., Dept. of College of Science and Engineering, Aoyama Gakuin University, Dr. Eng. 


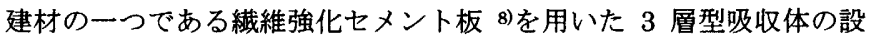
計・試作を行った。そして吸収体の構成材料の含水率の変動, 設置環 境の温湿度条件と材料の含水率変動範囲, さらにそれらを考慮した吸 収体の吸収性能の評価を行った。

\section{2. 設計}

2 つの材料を重ねる 2 層吸収体においては理論的に 2 つの吸収ピ 一クができることが知られている9)ので， 2 層をべースに吸収ピーク の周波数帯域幅を広げる工夫として層と層の間に空気層を入れた 3 層構造を考え， 3 層型電波吸収体の検討（空気層厚が $0 \mathrm{~mm}$ の場合の 2 層構造を含む) を行った。

\section{1 基本式}

この構造において, 表面と層 1 , 層 1 と層 2 , 及び層 2 と層 3 との 境界面の背面インピーダンスをそれぞれ $\dot{\mathrm{Z}}_{1}, \dot{\mathrm{Z}}_{2}, \dot{\mathrm{Z}}_{3}$ とすると，これ らは各層の特性インピーダンス, 伝播定数, 厚さ(それぞれ $\dot{Z}_{\mathbf{c}_{1}}, \dot{Z}_{\mathrm{c}_{2}}$, $\left.\dot{Z}_{\mathrm{c}_{3}}, \quad \dot{\gamma}_{1}, \quad \dot{\gamma}_{2}, \quad \dot{\gamma}_{3}, \mathrm{~d}_{1}, \mathrm{~d}_{2}, \mathrm{~d}_{3}\right)$ から以下のように求められる 10 )。な お，検討している材料は誘電体なので比透磁率は 1.0 と考えられる ため, 以下の式では $\mu$ を省略してある。

$$
\begin{aligned}
& \dot{\mathrm{Z}}_{3}=\dot{\mathrm{Z}}_{\mathrm{c} 3} \cdot \tanh \dot{\gamma}_{3} d_{3} \\
& \dot{\mathrm{Z}}_{2}=\dot{\mathrm{Z}}_{\mathrm{c} 2} \cdot \frac{\dot{\mathrm{Z}}_{3}+\dot{\mathrm{Z}}_{\mathrm{c} 2} \cdot \tanh \dot{\gamma}_{2} d_{2}}{\dot{\mathrm{Z}}_{\mathrm{c} 2}+\dot{\mathrm{Z}}_{3} \cdot \tanh \dot{\gamma}_{2} d_{2}} \\
& \dot{\mathrm{Z}}_{1}=\dot{\mathrm{Z}}_{\mathrm{cl} 1} \cdot \frac{\dot{\mathrm{Z}}_{2}+\dot{\mathrm{Z}}_{\mathrm{cl}} \cdot \tanh \dot{\gamma}_{1} d_{1}}{\dot{\mathrm{Z}}_{\mathrm{c} 1}+\dot{\mathrm{Z}}_{2} \cdot \tanh \dot{\gamma}_{1} d_{1}}
\end{aligned}
$$

ここで, 自由空間の特性インピーダンスを $\mathrm{Z}_{0}$ とすると, 層 $N$ にお ける TE 波と TM 波の特性インピーダンス $\dot{\mathrm{Z}}_{\mathrm{C} N}$ と伝播定数 $\dot{\gamma}_{N}$ は, 層 $N$ における複素比誘電率 $\dot{\varepsilon} N$ と入射角度 $\theta_{i}$, 真空での波長 $\lambda_{0}$ 上り

$$
\begin{aligned}
\dot{\gamma}_{N} & =j \frac{2 \pi}{\lambda_{0}} \sqrt{\dot{\varepsilon}_{N}-\sin ^{2} \theta_{i}} \\
\dot{\mathrm{Z}}_{\mathrm{CN}} \mathrm{te} & =\frac{\mathrm{Z}_{0}}{\sqrt{\dot{\varepsilon}_{n}-\sin ^{2} \theta_{i}}} \quad \mathrm{Z}_{\mathrm{CN}} \mathrm{tm}=\frac{\dot{\mathrm{Z}}_{0} \cdot \sqrt{\dot{\varepsilon}_{n}-\sin ^{2} \theta_{i}}}{\dot{\varepsilon}_{n}}
\end{aligned}
$$

と表せる。そして TE 波と TM 波の反射係数「te，广 $\dot{\Gamma t m}$ は

$$
\dot{\Gamma} \mathrm{te}=\frac{\dot{Z}_{1}-Z_{0} / \cos \theta_{i}}{\dot{Z}_{1}+Z_{0} / \cos \theta_{i}} \dot{\Gamma} \mathrm{tm}=\frac{\dot{Z}_{1}-Z_{0} \cdot \cos \theta_{i}}{\dot{Z}_{1}+Z_{0} \cdot \cos \theta_{i}}
$$

となる。ここで, 層 2 は空気なのでその比誘電率は既知（1.0）で, 未知数は 3 つの層の厚さと層 1 , 層 3 の複素比誘電率の実部項, 虚 数項の $7 つ\left(\mathrm{~d}_{1}, \mathrm{~d}_{2}, \mathrm{~d}_{3}, \varepsilon_{1}^{\prime}, \varepsilon_{1}^{\prime}, \varepsilon_{3}^{\prime}, \varepsilon_{3}{ }_{3}\right)$ である。このような 3 層 型吸収体の典型的な構成を図 1 示す。

ここで扱うような窭業系の材料は, 材料中の含水率の変化に伴っ て複素比誘電率が増減することが広く知られおり，室内空間で用い る場合の含水率変動内では, 複素比誘電率の実部・虚部項ともその 含水率と線形関倸があることを過去 らに明らかにした。この関係を使 って層 1 と層 3 の複素比誘電率をそれらの含水率で表すことにより， この系の未知数を $5 つ\left(\mathrm{~d}_{1}, \mathrm{~d}_{2}, \mathrm{~d}_{3}, \mathrm{wc}_{1}, \mathrm{wc}_{3}\right)$ にすることが可能とな る。この基本式を元に, 図 2 に示すような 3 つの工程（材料選定, 粗調査, 詳細調查) により, 実際の吸収体の設計を行う。

\section{2 織維強化セメント板による吸収体設計一材料選定}

材料としては, 含水率の変動が少ない繊維強化セメント板（スレ ートボードフレキシブル板 8)：JIS A 5430）を選定し，複素比誘電率 と含水率との実験的関係式を導出する。本検討では，市販されてい

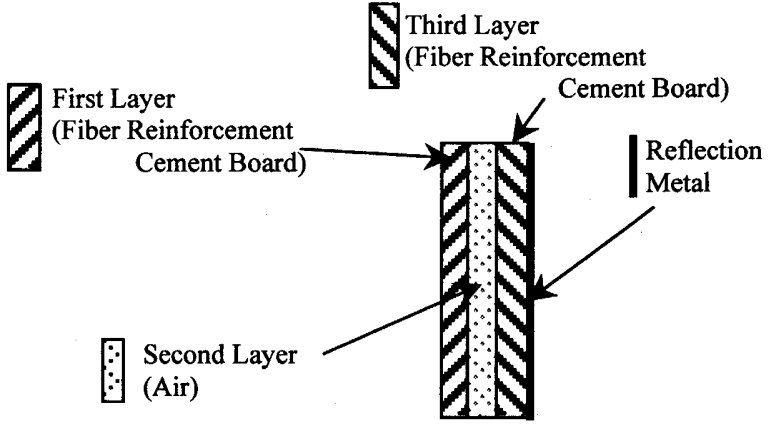

Fig.1 Structure for the three layer type absorber

\section{Material Selection}

- Selection of building materials for layer 1 and layer3 for the Three-Layers-Type EM-Absorber (3L Absorber)

- Conduction of experimental equation of the relation between complex relative permittivity and water content for the above materials

$\Rightarrow$ Experimental equations

\section{Course Survey}

- Set target absorption performance for frequency range, oblique incident, and polarization. Typically absorption performance set $12 \mathrm{~dB}$ for normal and 30 degree of TE and TM polarization wave.

- Set condition of the 3L Absorber, such as thickness of each and/or total layer, range of water content.

- Calculation absorption performance by using equation (1) to (6) and conducted experimental equations above.

$\Rightarrow$ Some combinations for thickness of each layer and

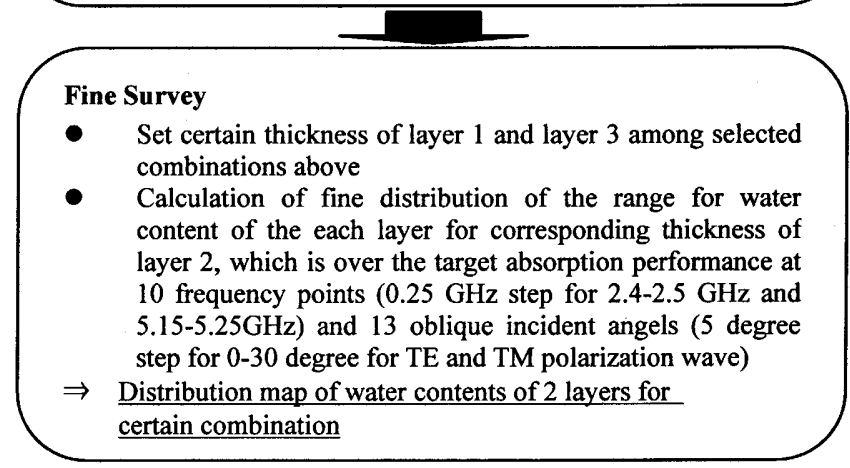

$\longrightarrow$

Final Combination of thickness and water content for each layer

Fig.2 Design flow for the absorber

る最も一般的な 2 つのタイプで 6 種類の厚さの試料（ $\mathrm{N}$ 社製 $3 ， 4$, $5,6 \mathrm{~mm}$ 厚のタイプ $\mathrm{A} と 8,12 \mathrm{~mm}$ 厚のタイプ B) を各 10 枚ずつ用 意し,ダブルリッチドホーンアンテナ(EMCO3115)とネットワーク アナライザー(Wiltron360B)を用いた自由空間反射損失法による反 射係数の測定 11) と反復計算 5 )によって複素比誘電率を算出した（試 料寸法 : $200 \mathrm{~mm}$ 角，測定周波数： $1 \sim 8.5 \mathrm{GHz}$ )。商業用材料を工場 で生産後，本測定用の寸法に切り出した上で上記の測定を行った。

この結果を図 3 に示す。2 つの絨維強化セメント板の含水率一複素 比誘電率曲線は, 室内空間での一般的な含水率範曲である 5 ～ $10 \%$ 


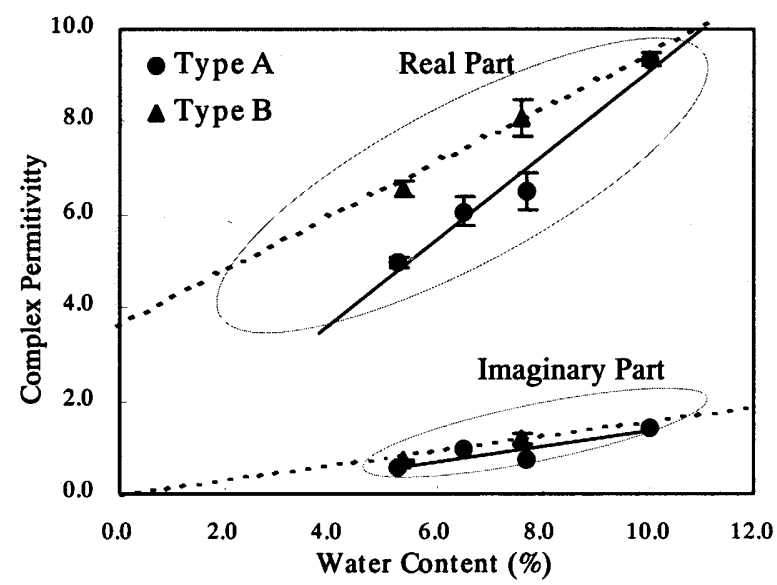

Fig.3 Distribution of the complex permittivity of fiber reinforced cement boards for various water content

Table1 Selected range of thickness and water content for each layer over

\begin{tabular}{|c||c|c|c|cc|c|}
\hline \multirow{2}{*}{ Case } & \multicolumn{3}{c|}{ Thickness (mm) } & \multicolumn{2}{c|}{ Water Content (\%) } & Selected \\
& $\mathrm{d}_{1}$ & $\mathrm{~d}_{2}$ & $\mathrm{~d}_{3}$ & $\mathrm{wc}_{1}$ & $\mathrm{wc}_{3}$ & number \\
\hline \hline \multirow{5}{*}{ Case 1 } & 3 & 3,4 & $28 \sim 32$ & $5.0 \sim 8.9$ & $8.0 \sim 10.0$ & 451 \\
& 4 & 2,3 & $28 \sim 31$ & $5.0 \sim 7.0$ & $8.5 \sim 10.0$ & 176 \\
& 5 & 2 & $28 \sim 30$ & $5.0 \sim 6.1$ & $8.6 \sim 10.0$ & 64 \\
& 6 & 1,2 & 28,29 & $5.1 \sim 5.5$ & $9.2 \sim 10.0$ & 24 \\
& 7 & 1 & 28 & $5.0,5.1$ & $9.4,9.5$ & 3 \\
\hline \multirow{5}{*}{ Case 2 } & $24 \sim 27$ & 5,6 & 9 & $6.4 \sim 7.7$ & $9.5 \sim 10.0$ & 13 \\
& $20 \sim 26$ & $5 \sim 19$ & 10 & $5.6 \sim 9.6$ & $7.8 \sim 10.0$ & 757 \\
& $20 \sim 25$ & $6 \sim 18$ & 11 & $6.2 \sim 9.6$ & $7.0 \sim 8.7$ & 400 \\
& $20 \sim 24$ & $7 \sim 16$ & 12 & $7.0 \sim 9.6$ & $6.1 \sim 7.1$ & 122 \\
& $20 \sim 22$ & $9 \sim 13$ & 13 & $8.1 \sim 9.5$ & $5.3 \sim 5.9$ & 25 \\
\hline
\end{tabular}

Table2 Selection procedure for the range of thickness and water content over $12 \mathrm{~dB}$

\begin{tabular}{|c||c|c|c|cc|c|}
\hline \multirow{2}{*}{ Step } & \multicolumn{7}{|c|}{ Thickness $(\mathrm{mm})$} & \multicolumn{2}{c|}{ Water Content(\%) } & Selected \\
& $\mathrm{d}_{1}$ & $\mathrm{~d}_{2}$ & $\mathrm{~d}_{3}$ & $\mathrm{wc}_{1}$ & wc $_{3}$ & number \\
\hline \hline \multirow{4}{*}{ Step 1 } & 3 & 3,4 & $28 \sim 32$ & $5.0 \sim 8.9$ & $8.0 \sim 10.0$ & 451 \\
& 4 & 2,3 & $28 \sim 31$ & $5.0 \sim 7.0$ & $8.5 \sim 10.0$ & 176 \\
& 5 & 2 & $28 \sim 30$ & $5.0 \sim 6.1$ & $8.6 \sim 10.0$ & 64 \\
\cline { 2 - 7 } Step 2 & 3 & 3,4 & 29 & $5.1 \sim 8.5$ & $9.3 \sim 10.0$ & 156 \\
& 3 & 3,4 & 30 & $5 \sim 8.1$ & $8.7 \sim 9.9$ & 167 \\
& 4 & 2,3 & 29 & $5.0 \sim 6.7$ & $9.1 \sim 10.0$ & 97 \\
\cline { 2 - 7 } Step3 & 3 & 3 & 29 & $5.8 \sim 8.5$ & $9.3 \sim 10.0$ & 107 \\
& 3 & 3 & 30 & $5.3 \sim 8.1$ & $8.7 \sim 9.8$ & 94 \\
& 4 & 3 & 29 & $5.0 \sim 6.7$ & $9.1 \sim 10.0$ & 57 \\
\hline
\end{tabular}

Table3 Selection procedure for the range of thickness and water content over $12 \mathrm{~dB}$ in case 2

\begin{tabular}{|c||c|c|c|c|c|c|}
\hline \multirow{2}{*}{ Step } & \multicolumn{3}{|c|}{ Thickness (mm) } & \multicolumn{2}{c|}{ Water Content(\%) } & Selected \\
& $\mathrm{d}_{1}$ & $\mathrm{~d}_{2}$ & $\mathrm{~d}_{3}$ & wc $_{1}$ & wc $_{3}$ & number \\
\hline \hline \multirow{3}{*}{ Step 1 } & $20 \sim 26$ & $5 \sim 19$ & 10 & $5.6 \sim 9.6$ & $7.8 \sim 10.0$ & 757 \\
& $20 \sim 25$ & $6 \sim 18$ & 11 & $6.2 \sim 9.6$ & $7.0 \sim 8.7$ & 400 \\
\cline { 2 - 7 } & 23 & $7 \sim 19$ & 10 & $6.7 \sim 8.1$ & $8.6 \sim 10.0$ & 181 \\
& 24 & $6 \sim 19$ & 10 & $6.2 \sim 7.7$ & $9.3 \sim 10.0$ & 183 \\
Step 2 & 25 & $6 \sim 17$ & 10 & $5.8 \sim 7.2$ & $8.7 \sim 9.9$ & 142 \\
& 23 & $7 \sim 16$ & 11 & $6.9 \sim 8.1$ & $9.1 \sim 10.0$ & 123 \\
\hline \multirow{5}{*}{ Step3 } & 23 & 8 & 10 & $7.7 \sim 8.0$ & $8.5 \sim 10.0$ & 26 \\
& 23 & 9 & 10 & $7.6 \sim 7.8$ & $8.9 \sim 10.0$ & 26 \\
& 24 & 7 & 10 & $7.2 \sim 7.5$ & $8.5 \sim 10.0$ & 28 \\
& 24 & 8 & 10 & $7.1 \sim 7.4$ & $8.6 \sim 10.0$ & 27 \\
\hline
\end{tabular}

程度では, 線形関係でありその傾きは異なっていること, 過去に行 った結果 (タイプ B試料に関する実験式 5) : 図中の点線) とよく一致 していることが分かる。

本検討では, 厚さの種類が $3 \mathrm{~mm} \sim 12 \mathrm{~mm}$ と幅広く市販されている タイプ Aのものを吸収材料として選択した。得られた, 複素比誘電 率·含水率の実験式を式(7)に示す。

$$
\varepsilon^{\prime}=0.909 \times w c+0.0164 \quad \varepsilon^{\prime \prime}=0.164 \times w c-0.293
$$

\section{2 維䧺強化セメント板による吸収体設計一粗調查及び詳䚀調查}

式(8)で定義される吸収性能 Ste, Stmを, 式(1)〜 (7)から得られ る反射係数 $\dot{\Gamma t e}, \dot{\Gamma t m}$ から, 対象周波数 $1 \sim 6 \mathrm{GHz}$ の帯域で各層の厚 さ $\mathrm{d}_{1}, \mathrm{~d}_{2}, \mathrm{~d}_{3}$ と層 1 と層 3 の含水率 $\mathrm{wc}_{1}, \mathrm{wc}_{3}$ により計算し, 目標吸 収性能を满足するこれらの組み合わせを調査する。

$$
\text { Ste }=-20 \log _{10}|\dot{\Gamma} \mathrm{te}| \quad S t m=-20 \log _{10}|\dot{\Gamma} \mathrm{tm}|
$$

目標吸収性能値は, TE・TM 偏波の斜入射 30 度及び垂直入射に対 して,2 つの無線 LAN 使用周波数带域の開始, 中心, 終了周波数 $(2.4 \mathrm{GHz}, 2.45 \mathrm{GHz}, 2.5 \mathrm{GHz}, 5.15 \mathrm{GHz}, 5.2 \mathrm{GHz}, 5.25 \mathrm{GHz})$ で $10 \mathrm{~dB}$ 及び $12 \mathrm{~dB}$ とした (無線 LAN 環境に対する必要吸収性能値は, 一つの指標として高谷ら ${ }^{12}$ )は 8dB, 守倉ら 1)は CIR (希望波対干渉 波電力比）として $12 \mathrm{~dB}$ をあげている)。

計算した篹囲は，建材ということを考慮に入れ，各層の厚さを $30 \mathrm{~mm}$ 以内で $0.1 \mathrm{~mm}$ 刻み, 総厚は $45 \mathrm{~mm}$ 以内とし, 含水率は, $5 \%$ 〜 $10 \%$ の篟囲を $0.1 \%$ 刻みで行い, その際複素比誘電率の周波数分散 は考虑せず一定値とした。

上記の計算により, 目標吸収性能值を满足する各層の厚さと含水 率の組み合わせが得られるが, その組み合わせは限定的である。表 1 に目標值を $12 \mathrm{~dB}$ としたときの結果を示すが, 建材層の厚さの連続 性に注目すると $2 つ$ 組み合わせ群に分けられる。ただし, 表 1 に 示した各変数の膂囲はそのすべての領域で目標値以上であるわけで はなく, その可能性のある範囲を示している(以下この筮囲を許容幅 と称する)。この表から 2 つの群に分けられた目標值を満たす層の厚 さや含水率の範囲の分布は, 首 1 と層 3 の厚さの比較により, 層 1 が層 3 より薄い場合を Case1, 厚い場合を Case2 とする。

この表から, 各層厚のうち許容幅が狭い層から順番に固定し, 各 層すべての厚さを固定した際の, 目標吸収性能値を満たす層 1 と層 3 の含水率分布の広い組み合わせを考えてみる。すなわち, Case1 で は, $\mathrm{d}_{1}$ と $\mathrm{d}_{2}$ が $\mathrm{d}_{3}$ よりも許容幅が狭いので, $\mathrm{d}_{1}$ を固定 $(3 \mathrm{~mm})$ し, その中で目標吸収性能値を満足する組み合わせの広い $d_{3}$ を調べる。 そして, さらに同様にして $\mathrm{d}_{2}$ を固定する。このようにして, 含水率 分布の広い $\mathrm{d}_{1}, \mathrm{~d}_{2}, \mathrm{~d}_{3}$ の組み合わせを求めることができる。表 2 に この絞込みの過程での各層の厚さと目標吸収性能值を満足する含水 率簿囲の広さ（ここでは, 含水率 $0.1 \%$ 刻み, 厚さ $0.1 \mathrm{~mm}$ 刻みで行 った計算のうち目標値を満足する組み合わせの数 : 表中の Selected number）を Case 1 の場合で示す。Case2 も同様にして各層の厚さ を絞り込むことができ, 表 3 にこの絞込まれた首 1 と層 3 の含水率 の分布篹囲の広さを示す。

表 2 と表 3 で示した絞り込みを行った結果から, Case1 の組み合 わせの方が Case2 に比べて, 目標值を满足する含水率の範囲が広い こと, Case1 は層 1 の含水率の分布範囲が層 3 のものより広く, 逆 


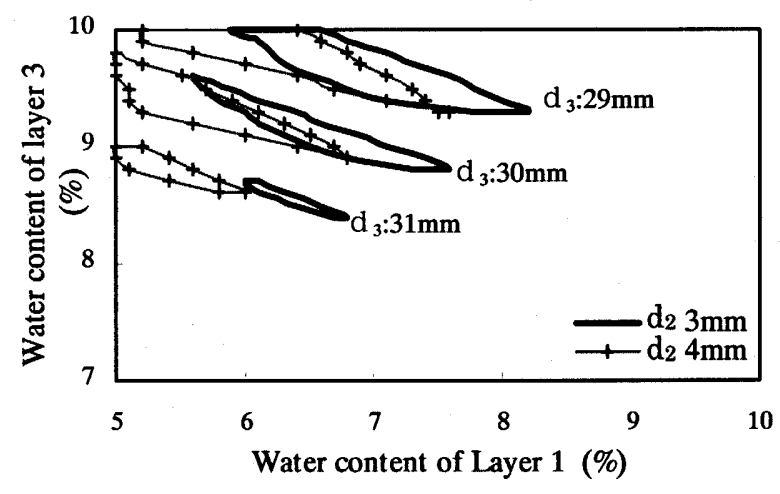

Fig.4 Area of water content of each layer over 12dB absorption

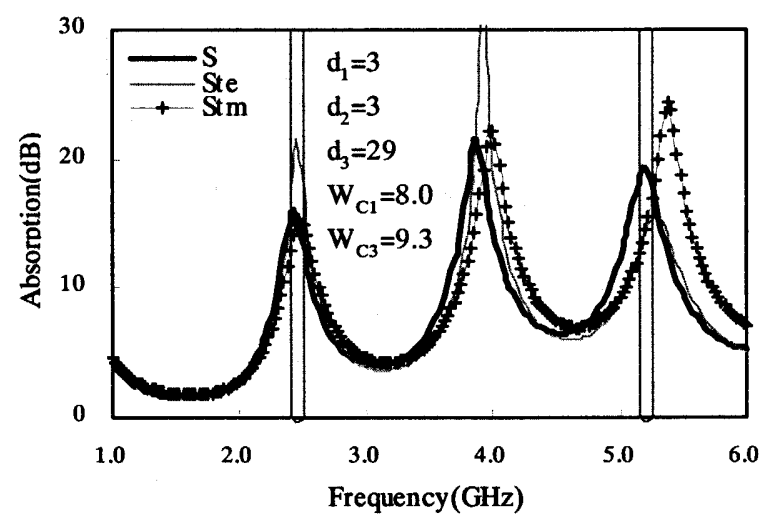

Fig.5 Frequency characteristics for the absorber

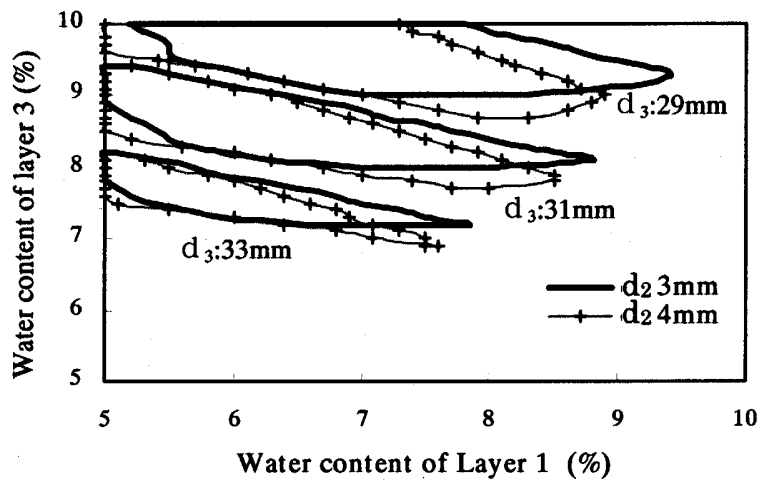

Fig.6 Area of water content of each layer over 10dB absorption

に Case2 は層 3 の方が首 1 より含水率の分布箶囲が広いことがわか る。これは, Case1 の組み合わせが, 含水率の変動, 特に表層 (層 1) の変動に対応しやすいことを示している。さらにこの構成は, 実際 上の施工を考虑すると, 部屋に面している表層が薄く, 下地などの 部分が厚いという点で実用的であるといえる。このことから，3 層型 電波吸収体を考える場合, 層 1 が層 3 より薄い Case1 の構成が適切 であることが明らかになった。

次に, 上記の絞り込まれた構成について, 複素比誘電率の周波数 分散を考虑した詳細調查を行うこととする。モルタルの複素比誘電 率の周波数分散については, 本計算周波数帯域 $1 \mathrm{GHz} \sim 6 \mathrm{GHz}$ 中では, 実部項は減少, 虚部項は微増するという報告 13)がある。筆者らも含
水率の異なる試料に対しての周波数分散を検討 》しており,複素比誘 電率の帯域中の代表值に対する $2.45 \mathrm{GHz}$ 帯と $5.2 \mathrm{GHz}$ 帯の複素比誘 電率実部項の增減は，含水率によらず一定であった。そこで，この 検討結果から対象とする 2 つの周波数帯域每に補正数を算出し, 含 水率一複素比誘電率実験式に反映 $(2.45 \mathrm{GHz}: 0.07,5.2 \mathrm{GHz}:-0.06)$ させた。ただし, 複素比誘電率の虚部項については, $2.45 \mathrm{GHz}$ と $5.2 \mathrm{GHz}$ での変動值が極めて小さいため, この検討においては考虑せ ず, 実部項のみ考虑した。そして, 計算は斜入射に対しては，0〜30 度まで 5 度刻み（TE, TM 偏波を含めて 13 回の計算）で, 周波数 に対しては $0.25 \mathrm{GHz}$ 刻み $(2.45 \mathrm{GHz}$ 帯と $5.2 \mathrm{GHz}$ 帯合わせて 10 回 の計算) で行った。

層 1 と層 3 の厚さの様々な組み合わせのうち, 最も含水率の分布 の広かったものは, 層 1 が $3 \mathrm{~mm}$, 層 3 が $29 \mathrm{~mm}$ (以下層 1 と層 3 の組み合わせを, 3-29 の様に示す)で, そのときの層 2 の厚さは $3 \mathrm{~mm}$ 及び $4 \mathrm{~mm}$ であった。その組み合わせを層 1 と層 3 の含水率をパラ メーターにして図 4 に, そして層 2 の厚さが $3 \mathrm{~mm}$ の場合の周波数 分布を図 5 に示す。目標值を満足する含水率範囲が層 1 の含水率方 向に広く分布している。この構成で, 層 3 の含水率を $9.6 \%$ とした際 には，層 1 の含水率は $6.6 \%$ か $7.6 \%$ と $1.1 \%$ の範囲で目標吸収性 能値 $12 \mathrm{~dB}$ を満足することがわかる。図 4 には, 層 3 の厚さを変化 させた際の分布も合わせて示しているが, 層 3 の厚さが $29 \mathrm{~mm}$ から $31 \mathrm{~mm}$ まで厚くなるにつれて分布の範围は，狭くなると共に層 3 の 含水率が低いほうへ移動していることがわかる。

最も含水率分布の広い組み合わせ 3-29 は, 層 3 の含水率が $9 \%$ $10 \%$ と室内の材料としては高い部分に集中している。そこで, 層 3 が厚くなるにつれて分布が層 3 の含水率の低い部分へ移動すること から, 目標吸収性能值を $10 \mathrm{~dB}$ とした場合で, 層 3 の厚さを $29 \mathrm{~mm}$, $31 \mathrm{~mm}, 33 \mathrm{~mm}$ の場合について, 目標值を满足する層 1 と層 3 の含 水率の範囲を図 6 に示す。この図から, 室内中に設置した際の織維 強化セメント板の中心的な含水率帯であると考えられる $7.5 \%$ 付近 でも，3-33 の組み合わせを選択することによって，目標吸収量を $10 \mathrm{~dB}$ とした場合, 十分に広い含水率範囲を実現できることがわかる。 例えば, 層 3 の含水率を $7.3 \%$ とした場合, 層 1 の含水率は $6.9 \sim 7.5 \%$ と $1.6 \%$ の幅において, 目標吸収性能を満足することができる。

\section{3. 材料の変動への対応性検封}

前項の吸収体の設計において $1 \%$ 程度の含水率の変動に対応でき ることを明らかにした。本項では，実際の吸収体設置熼境において 材料の含水率がどの程度変動するのかを検討した。図 7 に無線 LAN の通信改善の検討を行うモデルルームでの 90 日間の温度と湿度の出 現頻度を示す。この部屋は空調設備がないため, 当事業所で一般居 室でも空調を行っていない時期（10月 2 日から 11 月 17 日：90日 間) での温湿度を 5 分ごとに「おんどとり RH : TR-72S」T\&D 社製 で測定した。測定位置は壁中央部で床からの高さ $750 \mathrm{~mm}$ である。 この図から、この期間中の測定結果は，温度については $18^{\circ} \mathrm{C} \sim 23^{\circ} \mathrm{C}$ の䇢囲に 97\%，湿度については 50RH\%〜 70RH\%の範囲に 87\%が 分布しており，温湿度条件として $18^{\circ} \mathrm{C} 50 \mathrm{RH} \%$ と $23^{\circ} \mathrm{C} 70 \mathrm{RH} \%$ 想定 すればよいことがわかる。

次に実際の使用する材料の含水率変動を調査した。試験に用いた 材料は, タイプ $\mathrm{A}$ の $3 \mathrm{~mm}$ 厚 (寸法 $200 \mathrm{~mm}$ 角) を 16 枚で, $20{ }^{\circ} \mathrm{C} 60 \%$ 


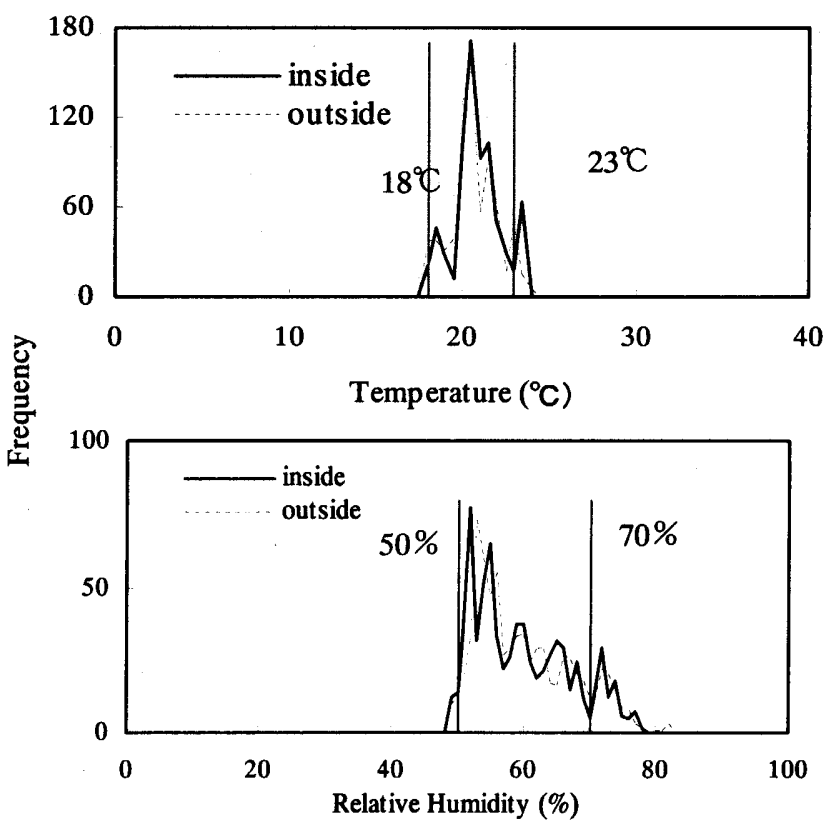

Fig. 7 Frequency of the temperature and relative humidity

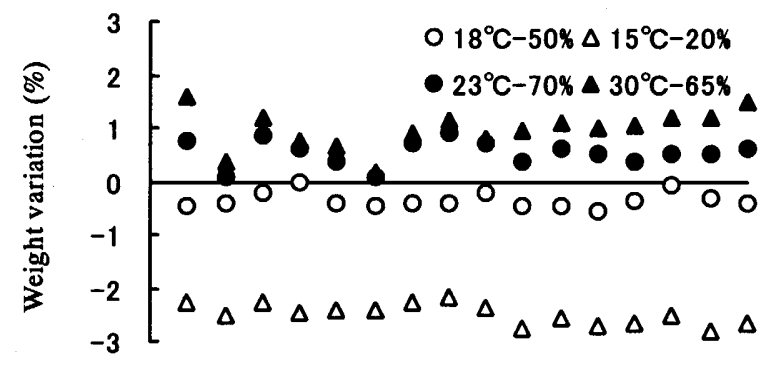

Fig. 8 Weight variation for samples in various environments

の恒温恒湿室, と恒温恒湿器で $18^{\circ} \mathrm{C} 50 \%, 23^{\circ} \mathrm{C} 70 \%, 15^{\circ} \mathrm{C} 20 \%$, $30^{\circ} \mathrm{C} 65 \%$ の睘境を作り, 重量変化がなくなるまでその男囲気中に静 置した。重量変化がなくなった時点で, 各試料の重さを測定し, $20^{\circ} \mathrm{C}$ 60\%での重量からの変化を示したのが図 8 である。ほとんどの試料 について, $18^{\circ} \mathrm{C} 50 \%$ 環境中と $23^{\circ} \mathrm{C} 70 \%$ 環境中での含水率の変動は, $1 \%$ 以内に収まっており, 16 試料の平均值は $0.89 \%$ であり, $30^{\circ} \mathrm{C} 65 \%$ 睘境中と比較しても $1.3 \%$ 程度に収まっていることがわかる。

吸収体が設置される室内瑟境では, 層 1 の試料の片面のみが室内 空気に触れているうえに, 空調により適当な温湿度状態に保たれて いる場合が多いため, 実際の変動はこの実験値よりは小さいことが 予想される。また, 層 3 は裹面が金属で塞打ちされており, その反 対面は層 1 とで挟まれた空気層であるため, 層 1 に比べて含水率の 変動は少ないと考えられる。さらに, 本実験で行った実環境と想定 されるもののうち, 最小温湿度環境 $\left(18^{\circ} \mathrm{C} 50 \%\right)$ と最大温湿度瑟境 (306 $65 \%)$ での含水率の差は $1.3 \%$ 程度であることを考虑すると， 3 層型吸収体の含水率の変動は, 層 1 において $1 \%$ 程度を想定すれば 十分であることがわかる。

\section{3 首型吸収体の試作}

前項までの検討を元に, 織維強化セメント板による 3 層型吸収体

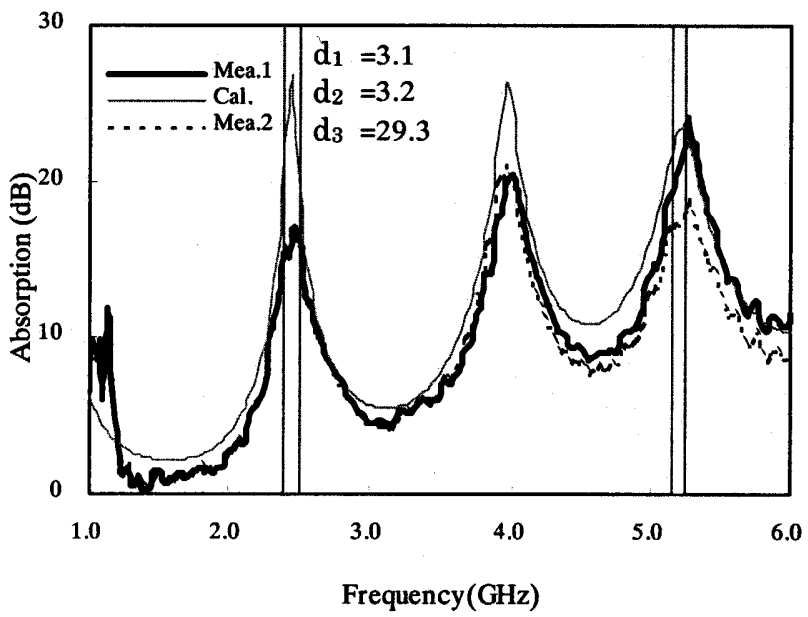

Fig.9 Measured absorption characteristics comparing to calculated one for the absorber

を試作した。用いた織維強化セメント板はタイプAである。 $2.45 \mathrm{GHz}$ 帶と $5.2 \mathrm{GHz}$ 帯において 30 度までの TE·TM 両偏波に対して, $12 \mathrm{~dB}$ 以上の吸収量を持つ Case 1 の組み合わせは，2.4 項で示したとおり $\mathrm{d}_{1}$ が $3 \mathrm{~mm}, \mathrm{~d}_{2}$ が $3 \mathrm{~mm}$ そして $\mathrm{d}_{3}$ が $29 \mathrm{~mm}$ の組み合わせである。し かし $29 \mathrm{~mm}$ の板は商業用としては流通していないため, 本検討では 比較的手に入れやすい $8 \mathrm{~mm}$ 厚 3 枚と $5 \mathrm{~mm}$ 厚 1 枚の組み合わせで $29 \mathrm{~mm}$ の厚さを実現することとした。使用した織維強化セメント板 は表面状態が極めて平坦であり過去の検討 6)から表裏の差がないこ とがわかっているため, 恒温恒湿器を使って表 2 で示した含水率篹 用の中に収まるように材料中の含水率を長期間かけ各材料中の含水 の分布が偏らないように調整したうえで, 積層したものを 1 層とし て取り扱った。

材料の寸法は $200 \mathrm{~mm}$ 角とし, 空気層である層 2 の $3 \mathrm{~mm}$ 厚は, 4 角にカムムテープを挟んで厚さを調整した。測定は 2.1 項と同様な湘 定系を用いて，1GHz〜 $6 \mathrm{GHz}$ の带域で行った。同時に各材料の厚 さと含水率を実湘し, 式(1)〜式(8)によって計算された吸収性能と合 わせて, 図 9 に測定の結果を示す。実測した値は, $\mathrm{d}_{1}$ は $3.1 \mathrm{~mm}, \mathrm{~d}_{2}$ は $3.2 \mathrm{~mm}, \mathrm{~d}_{3}$ は $29.3 \mathrm{~mm}(8.05 \mathrm{~mm}, 8.06 \mathrm{~mm}, 8.06 \mathrm{~mm}, 5.14 \mathrm{~mm})$, $\mathrm{wc}_{1}$ は $5.9 \%, \mathrm{wc}_{3}$ は $9.5 \%(9.4 \%, 9.5 \%, 9.6 \%, 9.6 \%)$ であった。 図中の太線は測定值を細線は計算值を示している。試作した吸収体 の測定值と実測した厚さと含水率によって求めた計算值とは, $2.45 \mathrm{GHz}$ 帯, $5.2 \mathrm{GHz}$ 帯を含む 3 つのピークを含めてよく一致して いると共に, 両周波数帯域すべてにわたって $15 \mathrm{~dB}$ 以上の吸収量を 示しており，本設計手法の有効性が確認できた。また，実測された 厚さと含水率から $\mathrm{TE}$ 及び TM 偏波 30 度斜入射の周波数特性の計算 を行い, 斜入射 30 度に対しても $15 \mathrm{~dB}$ 以上の吸収量を持っているこ とを確認した。

さらに，この試料を使って含水率が変動した際の吸収量の変化を 確諗するために, 層 1 に用いた $3 \mathrm{~mm}$ 厚の試料を $30^{\circ} \mathrm{C} 65 \%$ 骞囲気中 に数時間設置し,含水量を $1 \%$ 程度増加させた状態での測定を行った。 その結果を図 9 に太点線で合わせて示す。その際, 層 3 の試料の重 量も合わせて測定し, 層 1 の含水率は $6.9 \%$, 層 3 の含水率は $9.4 \%$ であった（先に試作した吸収体の含水率とは層 1 で+1\%, 層 3 で $-0.1 \%$ の增減)。この図から $5.2 \mathrm{GHz}$ 帯超のピークでの吸収量は低下 
しているが, 含水率が $1 \%$ 程度変動しても $2.45 \mathrm{GHz}$ 帯, $5.2 \mathrm{GHz}$ 帯 にわたって $15 \mathrm{~dB}$ 以上の吸収性能を維持していることがわかる。

ここで用いた吸収体の首 1 は $3 \mathrm{~mm}$ 程度の厚さであるが, 材料自体 で所望の曲け強度や耐衝撃性は保持 8)しており，さらに空気層の $3 \mathrm{~mm}$ を確保するためのスペーサーや層 $3(29 \mathrm{~mm})$ と複合することに よって衝撃や曲げ荷重或いは材料自体のそりなどに対しても十分対 応可能な構成となっている。

\section{5. おわりに}

一般建材としてよく使用されている繊維強化セメント板を使って 2 つの周波数帯域の無線 LANに対応した 3 層型電波吸収体の検討を 行った。まず, 3 首型電波吸収体の基本的な設計手法を説明した上で, 3つの段階からなる設計手法を明らかにした。そして本設計手法によ る 3 層型電波吸収体に関して行った検討により明らかになったこと は，以下のとおりである。

1. 3 層構造のうち, 層 1 が層 3 より薄い Case が,・層 1 の含水 率変動に広く对応でき, 施工を考虑しても, 適切な構成であ ること。

2. 得られた構成は, 層 3 の含水率を適切に設定した場合には, $1.1 \%$ 変動内で 2 つの無線 LAN 周波数帯域で 30 度までの $\mathrm{TE} \cdot \mathrm{TM}$ 斜入射において, 所定の目標吸収性能值である $12 \mathrm{~dB}$ を満足すること。

3. 本検討で用いた織維強化セメント板を $30^{\circ} \mathrm{C} 65 \%$ 環境や $18^{\circ} \mathrm{C}$ $50 \%$ 環境などでの含水率の変動を定量的に調查した結果，そ の含水率の変動は $1.3 \%$ 程度であり,このことから本吸収体が 設置される場所を想定した場合に，考慮すべき層 1 の含水率 変動は $1 \%$ 程度であること。

4. 3 層型吸収体を試作しその吸収量を測定した結果，実測した 厚さや含水率から求めた計算値とよい一致をし，2 つの周波 数帯域にわたって $15 \mathrm{~dB}$ を超える吸収性能を確認した。さら に, 層 1 の含水率を $1 \%$ 程度変化させても上記の吸収性能を 満足することから，本吸収体が含水率の変動にも対応できる ことを実証した。
今後は, 織維強化セメント板を用いた 3 層型電波吸収体の施工を 行い，部屋レベルでの吸収体の設置効果を確認する予定である。

参考文献

1) 守倉正博, 松江英明, : IEEE802.11 準拠無線 LAN の動向,信学論(B) vol.J84-B, no.11, pp.1918-1927, 2001.11

2) 木村健一：無線 LAN 用電波吸収体，月刊 OHM，no.5, 2004.5

3) 河辺伸二，池田哲夫，若田佳希，小西正夫：淮マイク口波帯用電波吸収 リサイクルボードの開発，日本建築学会構造系論文集，No.579, pp.1-5, 2004.5

4）遠藤哲夫，花沢理宏，橋本修，： $\lambda / 4$ 型電波吸収石育术 -ドに関する基䊙 検討，日本建築学会環境系論文集，第 568，pp.127-132，2003.6

5) Kimura, K. and Hashimoto, O.: An Experimental Study on the Calculation of the Complex Permittivity for Building Materials from the Reflection Loss by Free Space Measurement, 䉓学論 C, vol.124, No.2, pp.381-387, 2004.2

6) 木村健一, 新納敏文, 橋本修 : 内装用建材の複素比誘電率とその変動に 関する検討, 日本建築学会環境系論文集, No.590,pp.57-63, 2005.4

7) 木村健一, 新納敏文, 橋本修：一般建材を使つた 3 層型電波吸収体の開 発に関する基磷的検討，日本建築学会大会学術講演梗栖集 D-1, 2004.8

8) せんい強化セメント板協会 : 技術資料スレート, 2004

9) 橋本修：電波吸収体のはなし，日刊工業新聞社，東京，2001.6

10) 清水康敬他，電磁波の吸収之遮蔽，日経技術図書，東京，1999.9

11）木村健一，久保知也，白水廣一，橋本修 : 自由空間法による複素誘電率 測定における試料寸法に関する実験的検討, 信学論(B), Vol. J85-B, No.11, pp.1964-1967, 2002.11

12) 前田祐二, 高谷和宏，：電波吸収パーティションを用いた $2.4 \mathrm{GHz}$ 帯無線 LAN 伝播特性改善効果の解析，1999 信学ソ大(通信) B-4-39, 1999.9

13) Rhim, H. C., and Buyuk0zturk, O. :Electromagnetic Properties of Concrete at Microwave Frequency Range, ACI Material Journal,Vol.95,pp.262-271, 1998 
Summary

Recently, wireless LAN is widely used around/inside building, and some problems have been appeared, such as multi-path fading or security. Some wave absorbers are proposed to solve these problems as a one of the counter plan. In this situation, we presented the three layers type absorber by only common building materials (the Absorber) to propose the better wireless communication environment, while other absorber is expensive and difficult for handling, comparing common building materials. The target of the absorption is $12 \mathrm{~dB}$ for two major wireless LAN frequency ranges up to 30 degree of TE and TM polarization wave including normal incident.

The Absorber has advantage of cost and handling, and absorber with two layers is widely known to have two absorption peaks. Most of building materials, however, have very low absorption, especially for oblique incident, even with two layers structure. So, we try to insert air layer into two building materials to increase the performance. Fig.1 shows the basic structure of the Absorber.

Fig. 2 shows the design procedure of the Absorber. The absorption of the Absorber could be calculated by gradually electric circuit equivalent equations with 9 unknown factors ( 3 thicknesses, 3 real parts and 3 imaginary parts for complex permittivities). By linear relationship between complex permittivity (real and imaginary) and water content in certain range (typically 5-10\%) shown in Fig.3, 9 factors can be reduced to 5 unknown factors (3 thicknesses and 2 water contents).

Table 1 shows the combination ranges for each layer and water content for type $\mathrm{A}$, which can be over $12 \mathrm{~dB}$ absorption, as results of the calculation for the Absorber by fiber reinforced cement board. As the first step, the course calculations are conducted in the range of 0 to $30 \mathrm{~mm}, 0.1 \mathrm{~mm}$ step for each layer and $5 \%$ to $10 \%, 0.1 \%$ step for water content. Selected number in the table means the number of combinations of three thicknesses and two water contents satisfied the target absorption (12dB for up to 30 degree TE and TM oblique incident). The results of course survey indicated only two combination ranges for type $A$ could be over the $12 \mathrm{~dB}$ among wide survey ranges for two types of fiber reinforced cement board, and case 1 have narrow ranges for $d_{1}$ and $d_{2}$, comparing that for $d_{3}$, and also have narrow ranges for $\mathrm{wc}_{3}$ comparing that for $\mathrm{wc}_{1}$.

Next, fine calculations are conducted to fix the thickness of each layer for the design of the Absorber. Table 2 and Table 3 show the fixing procedure for the thickness of the layer in the order of narrow range. The results of the fine calculation indicate fixed combination for case 1 has wide range for wc $\mathrm{c}_{1}$ comparing that for case 2. This property is suitable for the Absorber, because layer 1 is more affected to the variation of temperature and humidity in the setting environment than layer 3. Fig. 4 and Fig. 6 show the area of water content of each layer over 12dB and 10dB, respectively, and Fig.5 shows frequency characteristics of the Absorber.

The frequency of the temperature and relative humidity for the experimental room are also investigated in order to estimate the condition of setting environment at Fig.7, and the variation of the water contents for fiber reinforced cement board are estimated in Fig.8.

Based on the above investigation, $3 \mathrm{~mm}$ thick fiber reinforced cement board and three $8 \mathrm{~mm}$ thick fiber reinforced cement boards $+5 \mathrm{~mm}$ thick fiber reinforced board are selected for layer $1(3 \mathrm{~mm})$ and layer $3(29 \mathrm{~mm})$. These boards set in humidifier to control the water content to fit one in the Table 1 ( $5.8 \%$ to $8.5 \%$ for layer 1 and $9.3 \%$ to $10 \%$ for layer 3). Fig.9 shows the comparison of measured absorption to calculation, which is conducted by measured thicknesses and water contents by each layer for normal incident. Calculated characteristics have very good agreement of the measurement for all frequency range and are confirmed over

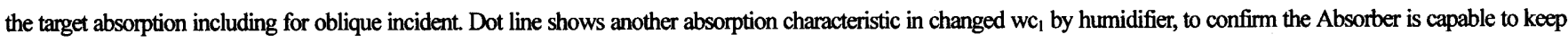
the certain absorption for varying water content in the range of $1 \%$. The dot line $\left(w_{1}=6.9 \%\right.$ and $\left.w_{3}=9.4 \%\right)$ is close to the bold line (wc $=5.9 \%$ and $\mathrm{wc}_{3}=9.5 \%$ ). The absorptions of these two lines are confirmed above $15 \mathrm{~dB}$ in 2 wireless LAN frequency ranges (2.4Ghz-2.5GHz and $5.15 \mathrm{GHz}-5.25 \mathrm{GHz}$ ).

The calculation of the absorber with the experimental equation of water content and complex permittivity is conducted few combinations (layers and water content) satisfying the target absorption $12 \mathrm{~dB}$ by wide range of survey. The absorption for the selected combination is confirmed over the $15 \mathrm{~dB}$, and the comparison of the measurement of experimented three layers type absorber and calculation with measured thickness and water content is conducted the validity of the design procedure presented this Letter, and effectiveness of the absorber even water content movement.

(2005年 5 月 10 日原稿受理, 2005 年 9 月 27 日採用決定 